JESTT Vol. 1 No. 8 Agustus 2014

PENGARUH PEMBIAYAAN MURABAHAH TERHADAP LABA

\title{
MELALUI VARIABEL INTERVENING PEMBIAYAAN BERMASALAH BANK UMUM SYARIAH \\ DI INDONESIA PERIODE 2009-2013
}

\author{
Zaim Nur Afif \\ Mahasiswa Program Studi S1 Ekonomi Islam -- Fakultas Ekonommi dan Bisnis -- Universitas \\ Airlangga \\ Email: zaimafif8@gmail.com \\ Imron Mawardi \\ Departemen Ekonomi Syariah - Fakultas Ekonomi dan Bisnis - Universitas Airlangga \\ Email: ronmawardi@gmail.com
}

\begin{abstract}
:
This study aims to investigate the effect of murabaha financing to profit through non performing financing as an intervening variable of islamic banks in Indonesia. This study uses quantitive approach with path analysis and three kinds of variables, they are murabaha financing as exogenous variable, non performing financing as intervening endogenous variable and profit as endogenous variable. The banks are used in this study is the Bank Muamalat Indonesia, Bank Syariah Mandiri, Bank Mega Syariah, Bank BRI Syariah, and Bank Syariah Bukopin. This study uses secondary data. Data collection is conducted by collecting semester financial statements for 2009-2013 period.

The results obtained that, murabaha financing has positive effects to non performing financing. It also happens to the effect of murabaha financing to profit. Meanwhile, non performing financing does not have effect to profit.
\end{abstract}

Key words: Islamic bank, murabaha financing, non performing financing, profit

\section{PENDAHULUAN}

\section{Latar Belakang}

Menurut

Undang-Undang

Perbankan Nomor 10 Tahun 1998, bank merupakan badan usaha yang menghimpun dana masyarakat dalam bentuk simpanan dan menyalurkan kepada masyarakat dalam bentuk kredit dan atau bentuk lainnya dalam rangka meningkatkan taraf hidup rakyat. Sebagai suatu lembaga keuangan, bank mempunyai kegiatan baik funding maupun financing atau menghimpun dan menyalurkan dana. Jadi sebagai lembaga intermediasi bank berperan menjadi perantara antara pihak yang kelebihan dana dan pihak yang membutuhkan dana.

Fungsi bank sebagai lembaga intermediasi khususnya dalam penyaluran kredit mempunyai peranan penting bagi pergerakan roda perekonomian secara keseluruhan. Pada level makro, bank merupakan alat dalam menetapkan kebijakan moneter sedangkan pada level mikro, bank merupakan sumber utama pembiayaan bagi para pengusaha maupun individu (Siringoringo, 2012).

$$
\text { Berbeda dengan bank }
$$

konvensional yang seluruh pembiayaan didasarkan pada bunga, bank syariah memiliki banyak ragam pembiayaan 
seperti murabahah, mudharabah, musyarakah, ijarah, salam, istishna, dan qardh. Meski begitu, pembiayaan murabahah merupakan jenis pembiayaan yang mendominasi di antara jenis pembiayaan yang terdapat pada perbankan syariah di Indonesia. Hal

Murabahah adalah penjualan barang oleh seseorang kepada pihak lain dengan pengaturan bahwa penjual berkewajiban untuk mengungkapkan kepada pembeli harga pokok dari barang dan marjin keuntungan yang dimasukkan ke dalam harga jual barang tersebut. Dalam hal ini bank syariah sebagai penjual dan nasabah sebagai pembeli. Dengan demikian, hal ini akan memudahkan bank syariah dalam memprediksi seberapa besar keuntungan yang akan didapatkan. Pembayaran angsuran pembiayaan murabahah ini dapat dilakukan secara tunai ataupun tangguh (Ascarya, 2007:164). Berdasarkan penjelasan di atas ditambah dengan mekanismenya yang mudah dan keuntungan yang pasti menjadikan pembiayaan murabahah banyak mendominasi penyaluran pembiayaan pada perbankan syariah di Indonesia.

Sebagai salah satu entitas bisnis keuangan yang mempunyai fungsi intermediasi, bank syariah dihadapkan dengan berbagai risiko. Salah satu risiko yang dihadapi bank syariah atas penyaluran pembiayaan yaitu pembiayaan non lancar mulai dari kurang lancar hingga macet yang dialami oleh nasabah atau disebut dengan Non
Performing Financing (NPF) (Djamil, 2012:66), dimana hal ini juga akan mempengaruhi kinerja bank syariah. Oleh karena itu, pihak perbankan syariah diharuskan untuk selalu menjaga keseimbangan antara pengelolaan risiko yang dihadapi dengan layanan yang diberikan kepada masyarakat.

Pembiayaan bermasalah (Non Performing Financingl adalah suatu keadaan dimana nasabah sudah tidak sanggup membayar sebagian atau seluruh kewajibannya kepada bank seperti yang telah diperjanjikan. Pembiayaan di bank syariah dapat mengalami masalah walaupun telah dilakukan berbagai analisis secara seksama (Kuncoro, 2002:462).

Pembiayaan akan berkualitas atau tidak berkualitas dimulai saat analisis pembiayaan. Kesalahan analisis pembiayaan akan menyesatkan keputusan pemberian pembiayaan. Keputusan pembiayaan yang salah merupakan potensi terjadinya kualitas pembiayaan yang rendah atau potensi terjadinya pembiayaan bermasalah. Kesalahan analisis pembiayaan sebagai akibat lemahnya kemampuan analisis pembiayaan dalam melaksanakan tugasnya dan anggota komite pembiayaan dalam mencermati usulan pembiayaan calon debitur. Penyebab pembiayaan bermasalah memang bisa dari faktor nasabah debitur itu sendiri misalnya kurangnya pengetahuan bisnis yang dibiayai bank, terjadinya mismanagement, konflik keluarga atau 
mungkin debitur sejak awal berniat menipu bank. Namun demikian analisis pembiayaan dan anggota komite pembiayaan tetap dianggap gagal mendeteksi faktor tersebut bila terjadi pembiayaan macet. (Taswan, 2010:451)

Tingkat pembiayaan bermasalah yang tinggi pada suatu bank syariah menunjukkan kualitas suatu bank syariah yang tidak sehat. Hal tersebut dapat menjadikan laba pada bank syariah menjadi turun (Fauzan, 2012). Margaretha (2009:61) menambahkan semakin besar ROA suatu bank, semakin besar pula tingkat keuntungan yang dicapai bank tersebut dan semakin baik pula posisi bank tersebut dan segi penggunaan aset.

Sementara itu, pengelolaan pembiayaan jual beli yang merupakan salah satu komponen penyusun aset terbesar pada perbankan syariah akan menghasilkan pendapatan berupa margin/mark up. Dengan diperolehnya pendapatan mark up tersebut, maka akan mempengaruhi besarnya laba yang diperoleh bank syariah. Serta pada akhirnya mampu mempengaruhi peningkatan laba bank syariah (Oktriani. 2011).

Berdasarkan latar belakang tersebut maka dapat dibuat rumusan masalah yaitu Apakah pembiayaan murabahah berpengaruh terhadap pembiayaan bermasalah Bank Umum Syariah di Indonesia? Apakah pembiayaan bermasalah berpengaruh terhadap laba Bank Umum Syariah di Indonesia? Apakah pembiayaan murabahah berpengaruh terhadap laba Bank Umum Syriah di Indonesia? Dan tujuan dari penelitian ini adalah untuk mengetahui pengaruh pembiayaan murabahah terhadap pembiayaan bermasalah Bank Umum Syariah di Indonesia, untuk mengetahui pengaruh pembiayaan bermasalah terhadap laba Bank Umum Syariah di Indonesia, dan untuk mengetahui pengaruh pembiayaan murabahah terhadap laba Bank Umum Syariah di Indonesia.

\section{LANDASAN TEORI DAN}

\section{PENGEMBANGAN HIPOTESIS}

\section{Bank Syariah}

Secara filosofis, bank syariah adalah bank yang aktivitasnya meninggalkan masalah riba (Machmud, 2010:4). Bank syariah adalah lembaga keuangan yang usaha pokoknya memberikan pembiayaan dan jasa-jasa lainnya dalam lalu lintas pembayaran serta peredaran vang yang pengoperasiannya disesuaikan dengan prinsip Islam. Sementara bank yang beroperasi sesuai prinsip syariah Islam adalah bank yang dalam beroperasinya itu mengikuti ketentuan-ketentuan syariah Islam (Muhammad, 2004:1).

Pada UU nomor 10 tahun 1998 tentang perubahan UU No. 7 Th.1992 tentang perbankan pasal (1) disebutkan bahwa:

Prinsip Syariah adalah aturan perjanjian berdasarkan hukum Islam antara bank dan pihak lain untuk menyimpan dana dan/atau pembiayaan kegiatan usaha, 
atau kegiatan lainnya yang dinyatakan sesuai dengan syariah, antara lain: pembiayaan berdasarkan prinsip bagi hasil (mudharabah), pembiayaan berdasarkan prinsip penyertaan modal (mudharabah), prinsip jual beli barang dengan memperoleh keuntungan (murabahah), atau pembiayaan barang/modal berdasarkan prinsip sewa murni tanpa pilihan (ijarah), atau dengan adanya pilihan pemindahan kepemilikan atas barang yang disewa dari pihak bank oleh pihak lain (ijarah wa istishna).

\section{Pembiayaan Murabahah}

Ada beberapa pengertian mengenai murabahah, di antaranya:

a. Dalam Penjelasan Pasal 19 huruf d Undang-Undang Nomor 21 Tahun 2008 tentang Perbankan Syariah disebutkan bahwa murabahah adalah akad pembiayaan suatu barang dengan menegaskan harga belinya kepada pembeli dan pembeli membayarnya dengan harga yang lebih sebagai keuntungan yang disepakati.

b. Dalam Pasal 1 angka 7 Peraturan Bank Indonesia (PBI) Nomor 7/46/PBI/2005 Tentang Akad Penghimpunan dan Penyaluran Dana Bagi Bank Yang Melaksanakan Kegiatan Usaha Berdasarkan Prinsip Syariah disebutkan bahwa murabahah adalah jual beli barang sebesar harga pokok barang ditambah dengan margin keuntungan yang disepakati.

c. Dalam Fikih Islam, Murabahah berarti suatu bentuk jual beli tertentu ketika penjual menyatakan biaya perolehan barang, meliputi harga barang dan biaya-biaya lain yang dikeluarkan untuk memperoleh barang tersebut, dan tingkat keuntungan (margin) yang diinginkan. Tingkat keuntungan ini bisa dalam bentuk persentase tertentu dari biaya perolehan. Pembayaran bisa dilakukan secara spot (tunai) atau bisa dilakukan di kemudian hari yang disepakati bersama (Ascarya, 2007:8182).

\section{Pembiayaan Bermasalah}

Pembiayaan

bermasalah merupakan pinjaman yang mengalami kesulitan pelunasan akibat adanya faktor kesenjangan dan atau karena faktor eksternal dari luar kendali calon debitur, pembiayaan bermasalah dapat diukur dari kolektibilitasnya yaitu merupakan gambaran kondisi pembayaran pokok dan bunga pinjaman serta kemungkinan diterimanya kembali dana yang ditanamkan (Siamat, 2004:174).

Penilaian atau penggolongan suatu pembiayaan ke dalam tingkat kolektivitas pembiayaan tertentu didasarkan pada kriteria kuantitatif dan kualitatif. Kriteria penilaian kolektivitas secara kuantitatif didasarkan pada keadaan pembayaran oleh nasabah yang tercermin dalam catatan pembukuan bank, yaitu mencakup ketepatan pembayaran/angsuran pokok, dan kewajiban lainnya (Kuncoro, 2002:253). 
Penilaian tersebut berdasarkan data historis dari masing-masing rekening pinjaman. Kriteria penilaian kolektivitas secara kualitatif didasarkan pada prospek usaha debitur dan kondisi keuangan usaha debitur. Dalam menentukan penilaian terhadap usaha debitur yang dinilai adalah kemampuan debitur membayar kembali pinjaman dari hasil usahanya sesuai perjanjian kreditnya yang dapat dideteksi dari proyeksi cash flow usahanya (Kuncoro, 2002:253).

\section{Faktor-Faktor Penyebab Pembiayaan Bermasalah}

Penyebab terjadinya pembiayaan bermasalah adalah kaeran kesulitankesulitan kevangan yang dihadapi nasabah. Penyebab kesulitan keuangan perusahaan nasabah dapat kita bagi dalam faktor internal dan faktor eksternal (Arifin, 2005:206).

(1) Faktor internal

Faktor internal adalah faktor yang ada dalam perusahaan sendiri, dan faktor yang paling dominan adalah faktor manajerial. Timbulnya kesulitan-kesulitan keuangan perusahaan yang disebabkan oleh faktor manajerial dapat dilihat dari beberapa hal, seperti kelemahan dalam kebijakan pembelian dan penjualan, lemahnya pengawasan biaya dan pengeluaran, kebijakan utang piutang uyang kurang tepat, penempatan yang berlebihan pada aktiva tetap, permodalan yang tidak cukup.

(2) Faktor eksternal
Faktor eksternal adalah faktorfaktor yang berada di luar kekuasaan manajemen perusahaan, seperti bencana alam, peperangan, perubahan dalam kondisi perekonomian dan perdagangan, perubahan-perubahan teknologi, dll.

Machmud (2010:117) mengemukakan ada beberapa faktor penyebab pembiayaan bermasalah (non performing financing), yaitu :

a. Kualitas cash flow

Analisis cash flow yang tidak mendalam dan komprehensif, cenderung "over optimistic", serta tidak tajam di dalam melakukan sensivitas sehingga dalam waktu singkat telah menjadi pembiayaan bermasalah (NPF).

b. Kualitas karakter nasabah

Kurangnya fungsi pengawasan dan pemantauan nasabah oleh pejabat bank syariah terkait. Kondisi ini menciptakan peluang bagi nasabah untuk melakukan sejumlah moral hazard seperti penyimpangan penggunaan dana dan atau/kelebihan likuiditas. Salah satu penyebab lemahnya pengawasan dan pemantauan kredit adalah jumlah account yang dikelola oleh seorang account manager tergolong banyak (rata-rata 20 sampai 30 account).

\section{Laba}

Menurut Mankiw (2000:325), laba adalah pendapatan total dikurangi biaya total. Berdasarkan pendapat ekonom laba diartikan sebagai laba ekonomis (economic profit), yakni pendapatan total perusahaan dikurangi seluruh biaya 
oportunitas yang ditanggung perusahaan dalam memproduksi barang dan jasa yang dijualnya. Sedangkan akuntan akan menghitung laba akuntansi atau laba pembukuan (accounting profit), yang merupakan pendapatan total perusahaan dikurangi biaya eksplisitnya saja.

Faktor-Faktor yang Mempengaruhi Laba Bank Syariah:

Laba bersih suatu bank dipengaruhi oleh dua faktor yang tidak selalu muncul dalam kegiatan bisnis (Nurkhosidah, 2009), yaitu:

1. Faktor perubahan sistem akuntansi dan biaya restrukturisasi

2. Faktor lainnya yang terdiri dari faktor intern dan faktor ekstern. Faktor intern meliputi adanya perbedaan aset dan liability baik dari jangka waktu, volume maupun jumlah. Faktor ekstern meliputi pengaruh globalisasi yang mengakibatkan perubahan suku bunga dan nilai tukar rupiah.

Sedangkan menurut Pramuka (2010) profitabilitas/laba bank syariah dipengaruhi oleh dua faktor yang terdiri dari:

1. Volume pembiayaan

Volume pembiayaan merupakan jumlah pendanaan yang dikeluarkan oleh bank syariah untuk mendukung investasi yang telah direncanakan selama waktu tertentu dari hasil penghimpunan dana pihak ketiga. Variabel besarnya pembiayaan ini diukur dengan rasio Financing to Deposit Ratio (FDR).

2. Resiko Pembiayaan

Resiko pembiayaan merupakan resiko yang diakibatkan oleh ketidakmampuan nasabah untuk mengembalikan sejumlah pinjaman yang diberikan oleh bank syariah beserta imbalannya sesuai dengan jangka waktu yang telah ditentukan sebelumnya. Variabel resiko pembiayaan diukur dengan rasio Non Performing Financing (NPF).

\section{Hipotesis}

Menurut Muhammad (2011:358): "Risiko pembiayaan muncul jika bank tidak bisa memperoleh kembali cicilan pokok dan atau bunga dari pinjaman yang diberikan atau investasi yang sedang dilakukannya. Penyebab utama terjadinya risiko pembiayaan adalah terlalu mudahnya bank memberikan pinjaman atau melakukan investasi karena terlalu dituntut untuk memanfaatkan kelebihan likuiditas, sehingga penilaian kredit kurang cermat dalam mengantisipasi berbagai kemungkinan risiko usaha yang dibiayainya". Hal itu menunjukkan bahwa semakin tinggi bank syariah menyalurkan pembiayaan, maka akan mengakibatkan risiko pembiayaan yang dinilai melalui Non Performing Financing (NPF) Muhammad (2004:143).

H1 : Pembiayaan Murabahah berpengaruh positif terhadap Pembiayaan 
Bermasalah Bank Umum Syariah di Indonesia

Risiko kredit berpengaruh negatif terhadap laba bank syariah sehingga semakin besar pembiayaan bermasalah akan mengakibatkan menurunnya laba yang juga berarti kinerja keuangan bank menurun karena resiko kredit semakin besar. Begitu pula sebaliknya, jika pembiayaan bermasalah turun, maka laba akan semakin meningkat, sehingga kinerja keuangan bank dapat dikatakan semakin baik. Adanya pembiayaan bermasalah yang cukup besar mengakibatkan hilangnya kesempatan untuk memperoleh keuntungan dari pembiayaan yang diberikan dan pada akhirnya akan menurunkan profitabilitas. (Rubby, 2013)

$$
\text { Menurut Nugroho (2012), }
$$

pembiayaan bermasalah mencerminkan risiko kredit, semakin tinggi pembiayaan bermasalah mengakibatkan semakin tinggi risiko kredit bermasalah yang berpotensi akan menurunkan keuntungan yang diperoleh. Semakin rendah pembiayaan bermasalah, maka laba bank syariah akan semakin tinggi ataupun sebaliknya jika pembiayaan bermasalah tinggi maka akan membuat laba bank syariah semakin menurun.

H2 : Pembiayaan Bermasalah berpengaruh negatif terhadap Laba Bank Umum Syariah di Indonesia

Pengelolaan pembiayaan murabahah yang merupakan salah satu komponen penyusun aset terbesar pada perbankan syariah akan menghasilkan pendapatan berupa margin/mark up. Dengan diperolehnya pendapatan mark up tersebut, maka akan mempengaruhi besarnya laba yang diperoleh bank syariah. Jika penyaluran pembiayaan tersebut dalam pengembaliannya berjalan dengan lancar, dimana semakin besar pendapatan maka semakin besar pula tingkat profitabilitas yang didapatkan oleh bank syariah (Oktriani, 2011).

$$
\text { Menurut Muhammad (2002:96) }
$$

dalam Setiawati (2009), pembiayaan murabahah yang diberikan oleh pihak bank akan menghasilkan margin/keuntungan bagi pihak bank. Kemudian keuntungan yang diperoleh pihak bank tersebut akan dihimpun beserta keuntungan pembiayaanpembiayaan yang lainnya dalam pool dana pendapatan yang kemudian akan disalurkan menjadi aset perusahaan, investasi dan modal.

\section{H3 : Pembiayaan Murabahah} berpengaruh positif terhadap Laba Bank Umum Syariah di Indonesia

\section{METODOLOGI PENELITIAN}

Pendekatan yang akan digunakan dalam penelitian ini adalah pendekatan kuantitatif. Pendekatan ini dilakukan dengan mengadakan pengujian hipotesis, pengukuran data, analisis data dan pembuatan kesimpulan. Sugiyono (2010:7) mengatakan "metode kuantitatif adalah metode penelitian yang berlandaskan pada filsafat positivisme, digunakan unuk meneliti pada populasi atau sampel 
tertentu, pengumpulan data menggunakan instrumen penelitian, analisis data bersifat statistik dengan tujuan menguji hipotesis yang telah ditetapkan." Menurut Indriantoro dan Supomo (1999:70) tujuan penelitian kuantitatif adalah untuk menguji atau verifikasi teori, meletakkan teori secara deduktif untuk kemudian menjadi landasan dalam hal penemuan dan pemecahan masalah penelitian.

Variabel yang digunakan dalam penelitian ini terdiri dari dua variabel, yaitu variabel eksogen dan variabel endogen. Variabel eksogen dalam penelitian ini adalah pembiayaan murabahah (X). Sedangkan variabel endogennya adalah laba (Y). Di dalam penelitian ini terdapat variabel endogen intervening, yaitu variabel yang dipengaruhi sekaligus berperan sebagai perantara. Variabel endogen intervening dalam penelitian ini adalah pembiayaan bermasalah (Z).

\section{Definisi Operasional Variabel}

Definisi Operasional Variabel dalam penelitian ini adalah:

1. Pembiayaan murabahah merupakan jumlah pembiayaan murabahah pada masing-masing bank syariah per semester selama periode 2009-2013 semester pertama. Dalam penelitian ini data pembiayaan murabahah yang digunakan dari nilai yang tampak dari neraca masing-masing bank yakni akun piutang murabahah yang dinyatakan dalam trilliun rupiah.
2. Pembiayaan bermasalah merupakan jumlah pembiayaan bermasalah pada masing-masing bank syariah per semester selama periode 2009-2013 semester pertama. Data pembiayaan bermasalah yang digunakan dari nilai yang tampak dari laporan rasio kevangan masing-masing bank. Akan tetapi, data yang diperlukan dalam penelitian ini adalah data nominal. Jadi, terlebih dahulu data rasio (persentase) tersebut diubah menjadi data nominal yang dinyatakan dalam trilliun rupiah.

Rumus total pembiayaan bermasalah (nominal):

Total pembiayaan bermasalah: $N P F(\%) x$ total pembiayaan $100 \%$

3. Laba merupakan jumlah laba bersih pada masing-masing bank syariah per semester selama periode 2009-2013 semester pertama. Dalam penelitian ini data laba yang digunakan dari nilai yang tampak dari laporan laba/rugi masing-masing bank, yakni akun Jumlah Laba (Rugi) yang dinyatakan dalam trilliun rupiah.

\section{Populasi dan Sampel}

Populasi yang digunakan dalam penelitian ini adalah jumlah laporan keuangan semesteran bank umum syariah dari awal berdiri hingga tahun 2013 semester pertama. Jumlah laporan keuangan semesteran bank umum syariah yang ada hingga tahun 2013 semester pertama sebanyakk 148 data. Teknik pengambilan sampel berdasarkan non 
probability sampling dimana tidak semua unit populasi memiliki kesempatan untuk dijadikan sampel penelitian. Peneliti harus jeli mengamati sifat-sifat populasi dengan bermodalkan pengetahuan pribadi dan opini yang telah diketahui sebelumnya (Bungin, 2005:109).

Sampel penelitian diambil secara purposive sampling karena hanya laporan kevangan semesteran dalam periode penelitian, yaitu tahun 2009 hingga 2013 semester pertama yang akan menjadi sampel di sini. Jumlah sampel dalam penelitian ini ada 45 laporan keuangan semesteran bank umum syariah yang diambil dari 5 bank syariah, yakni Bank Muamalat Indonesia, Bank Syariah Mandiri, Bank Mega Syariah, BRI Syariah, dan Bank Syariah Bukopin.

\section{Teknik Analisis}

Teknik analisis data yang digunakan dalam penelitian ini adalah analisis jalur (path analysis). Penamaan struktural pada penelitian pengaruh pembiayaan murabahah terhadap pembiayaan bermasalah dan laba bank umum syariah di Indonesia dapat ditunjukkan melalui persamaan sebagai berikut:

$$
\begin{gathered}
Z=b_{1} X+e \\
Y=b_{2} Z+b_{3} X+e
\end{gathered}
$$

Keterangan:

$\mathrm{X}=$ Pembiayaan Murabahah

Z= Pembiayaan Bermasalah

$Y=L a b a$

$b_{1}, b_{2}, b_{3}=$ Koefisien jalur

$\mathrm{e}=$ standard error

\section{HASIL PENELITIAN DAN PEMBAHASAN Uji Outlier}

Uji outlier merupakan uji yang digunakan untuk mengetahui apakah data terdistribusi secara normal. Jika tidak, maka dilakukan eliminasi data outlier atau data ekstrim. Dengan kata lain, eliminasi data outlier tidak akan dilakukan selama data telah terdistribusi secara normal.

Uji outlier terdiri dari univariate dan multivariate. Pengujian outlier univariate dilakukan dengan mengamati nilai Z score yang telah diolah dengan menggunakan software SPSS. Data dikatakan tidak outlier jika mempunyai nilai maksimum kurang dari dan minimum lebih dari \pm 3 (Ferdinand, 1999). Pada uji outlier univariate ini terdapat dua data yang outlier, sehingga harus dilakukan eliminasi data. Dengan demikian, data observasi dalam penelitian ini berkurang menjadi 43 .

Selanjutnya, data observasi dalam pengujian outlier multivariate dilakukan dengan pengamatan nilai Mahalanobis yang terdapat pada software AMOS. Jika nilai p1 dan/atau p2 kurang dari 0,05 maka data dikatakan outlier (Santoso, 2007:75). Pada uji ini, masih ada data yang outlier sehingga harus dilakukan eliminasi. Dengan demikian data observasi dalam penelitian ini berkurang menjadi 36 .

\section{Uji Normalitas}

Normalitas terjadi apabila skor pada tiap variabel mengikuti distribusi normal. Pengujian ini dilakukan dengan pengamatan nilai CR skewness (kemiringan) dan CR kurtosis 
(keruncingan). Data dikatakan berdistribusi normal jika mempunyai nilai CR skewness dan kurtosis sebesar $\pm 2,58$ (Hapsari, 2013) dengan tingkat signifikansi sebesar 5\%. Pada penelitian ini data terdistribusi normal karena nilai $C R$ skewness (kemiringan) dan CR kurtosis (keruncingan) masing-masing variabel berada di antara $-2,58$ dan 2,58.

\section{Pengujian Hipotesis}

$$
\text { Setelah dilakukan pengujian }
$$
asumsi, selanjutnya dilakukan pengujian hipotesis pada data observasi. Pengujian hipotesis dilakukan dengan mengkonversi diagram jalur yang telah dibuat sebelumnya menjadi sebuah gambar persamaan struktural dengan menggunakan software AMOS (Analysis of Moment Structure).

Pada pengujian ini diperoleh dua persamaan struktural, yaitu:

\section{Pembiayaan Bermasalah $=0,874$ Pembiayaan Murabahah}

Laba $=0,793$ Pembiayaan Murabahah + 0,06 Pembiayaan Bermasalah

Kedua persamaan di atas dapat diinterpretasikan sebagai berikut:

1. Koefisien jalur Pembiayaan Murabahah sebesar 0,874 dengan probabilitas yang ditunjukkan pada tabel 4.5 sebesar 0,001. Artinya, variabel Pembiayaan Murabahah berpengaruh positif terhadap Pembiayaan Bermasalah. Dengan kata lain, setiap terjadi kenaikan sebesar satu satuan pada nilai Pembiayaan Murabahah maka akan menaikkan nilai Pembiayaan Bermasalah sebesar 0,874 satuan.

2. Koefisien jalur Pembiayaan Bermasalah sebesar 0,06 dan koefisien Pembiayaan Murabahah sebesar 0,793 dengan probabilitas sebesar masing-masing 0,746 dan 0,001. Artinya, variabel Pembiayaan Bermasalah tidak berpengaruh terhadap variabel Laba dan variabel Pembiayaan Murabahah berpengaruh positif terhadap Laba. Dengan kata lain, setiap terjadi kenaikan sebesar satu satuan pada Pembiayaan Bermasalah maka tidak akan berpengaruh terhadap nilai Laba. Sebaliknya, setiap terjadi kenaikan sebesar satu satuan pada nilai Pembiayaan Murabahah maka akan meningkatkan nilai Laba sebesar 0,793 .

\section{Analisis Pengaruh Langsung, Pengaruh Tidak Langsung, dan Pengaruh Total}

Pada analisis ini dapat diketahui koefisien jalur untuk pengaruh langsung, pengaruh tidak langsung dan pengaruh total dari masing-masing variabel. Koefisien jalur untuk pengaruh langsung Pembiayaan Murabahah terhadap Pembiayaan Bermasalah adalah 0,874; Pembiayaan Bermasalah terhadap Laba adalah 0,060 dan Pembiayaan Murabahah terhadap Laba adalah 0,793. Koefisien jalur untuk pengaruh tidak langsung Pembiayaan Murabahah terhadap Laba adalah 0,053. 
Koefisien jalur untuk pengaruh total seluruhnya didapatkan dari hasil penjumlahan koefisien pengaruh langsung dan pengaruh tidak langsung. Pengaruh total Pembiayaan Murabahah terhadap Pembiayaan Bermasalah dan Pembiayaan Bermasalah terhadap Laba adalah tetap, yaitu sebesar masingmasing 0,874 dan 0,060. Hal ini dikarenakan kedua hubungan tersebut tidak memiliki pengaruh tidak langsung. Sedangkan koefisien pengaruh total Pembiayaan Murabahah terhadap Laba adalah sebesar 0,845.

\section{Pengaruh Pembiayaan Murabahah terhadap Pembiayaan Bermasalah}

Berdasarkan hasil penelitian, variabel pembiayaan murabahah berpengaruh positif terhadap terhadap pembiayaan bermasalah dengan probabilitas 0,001 dan tingkat pengaruh sebesar 0.874. Hal ini berarti setiap kenaikan pembiayaan murabahah sebesar satu satuan maka akan meningkatkan pembiayaan bermasalah sebesar 0,874. Dengan demikian, hasil analisis kuantitatif dalam penelitian ini sesuai dengan hipotesis sebelumnya, yaitu pembiayaan murabahah berpengaruh positif terhadap pembiayaan bermasalah.

Hasil penelitian ini sejalan dengan hasil penelitian yang telah dilakukan oleh Sholihah (2013) yang berjudul "Analisis Pengaruh Inflasi, GDP, Financing to Deposit Ratio (FDR) dan Return Pembiayaan Profit dan Loss Sharing terhadap Non Performing Financing (NPF) pada Perbankan Syariah di Indonesia". Penelitian tersebut menunjukkan hasil bahwa variabel Financing to Deposit Ratio (FDR) berpengaruh secara positif dan signifikan terhadap Non Performing Financing (NPF), yakni semakin tinggi Financing to Deposit Ratio (FDR) sebuah bank, maka akan meningkatkan Non Performing Financing (NPF) pada bank tersebut. Pengaruh ini terjadi karena kurang kehati-hatian dan ketelitian pihak bank syariah dalam menilai dan memperkirakan kondisi ekonomi yang terjadi serta lingkungan sekitar. Jika bank mempunyai Financing to Deposit Ratio (FDR) yang sangat tinggi, maka bank syariah akan mempunyai risiko tidak tertagihnya pembiayaan yang tinggi dan pada titik tertentu bank akan mengalami kerugian.

Menurut Muhammad (2011:358): "Risiko pembiayaan muncul jika bank tidak bisa memperoleh kembali cicilan pokok dan atau bunga dari pinjaman yang diberikan atau investasi yang sedang dilakukannya. Penyebab utama terjadinya risiko pembiayaan adalah terlalu mudahnya bank memberikan pinjaman atau melakukan investasi karena terlalu dituntut untuk memanfaatkan kelebihan likuiditas, sehingga penilaian kredit kurang cermat dalam mengantisipasi berbagai kemungkinan risiko usaha yang dibiayainya".

Sebagai lembaga intermediasi sesuai Undang-Undang Perbankan Nomor 10 Tahun 1998, bank syariah telah 
menjalankan fungsinya sebagai penghimpun dana masyarakat dalam bentuk simpanan dan menyalurkan kepada masyarakat dalam bentuk kredit dan atau bentuk lainnya dalam rangka meningkatkan taraf hidup rakyat. Hal ini sesuai dengan Firman Allah SWT dalam Q.S. Al Maa-idah ayat 2:

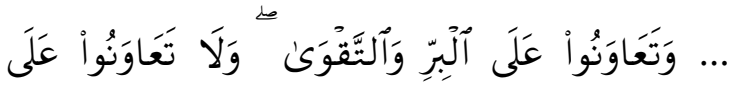

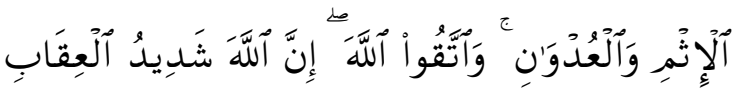

...Wa ta'ā wanū 'ala al-birri wa't-Taqwā wa lā ta'ā wanū 'ala al-iśmi wa al-'udwāni wa't-Taqu'l-Lāha inna'l-Lāha syadìdu al'iqābi.

"....dan tolong-menolonglah kamu dalam (mengerjakan) kebajikan dan takwa, dan jangan tolong-menolong dalam berbuat dosa dan pelanggaran. dan bertakwalah kamu kepada Allah, Sesungguhnya Allah Amat berat siksa-Nya."

\section{Pengaruh Pembiayaan Bermasalah terhadap Laba}

Berdasarkan hasil penelitian, variabel pembiayaan bermasalah tidak berpengaruh terhadap terhadap laba. Hal ini berarti setiap kenaikan pembiayaan bermasalah sebesar satu satuan maka tidak akan meningkatkan atau menurunkan nilai laba. Sesuai hasil estimasi Regression Weight dalam penelitian ini menunjukkan bahwa tingkat probabilitas pembiayaan bermasalah terhadap laba adalah sebesar 0,746 , nilai ini lebih besar daripada 0,05 . Oleh karena itu, hasilnya tidak signifikan atau tidak ada pengaruh. Dengan demikian, hasil analisis kuantitatif dalam penelitian ini tidak sesuai dengan hipotesis sebelumnya, yaitu pembiayaan bermasalah berpengaruh negatif terhadap laba.

Pada dasarnya, pembiayaan bermasalah akan mempengaruhi laba. Adanya pembiayaan bermasalah yang cukup besar mengakibatkan hilangnya kesempatan untuk memperoleh keuntungan dari pembiayaan yang diberikan dan pada akhirnya akan menurunkan profitabilitas. (Rubby, 2013)

$$
\text { Menurut Pramuka (2010) }
$$

profitabilitas/laba bank syariah dipengaruhi oleh dua faktor yang terdiri dari:

1. Volume pembiayaan

Volume pembiayaan merupakan jumlah pendanaan yang dikeluarkan oleh bank syariah untuk mendukung investasi yang telah direncanakan selama waktu tertentu dari hasil penghimpunan dana pihak ketiga. Variabel besarnya pembiayaan ini diukur dengan rasio Financing to Deposit Ratio (FDR).

2. Resiko Pembiayaan

Resiko pembiayaan merupakan resiko yang diakibatkan oleh ketidakmampuan nasabah untuk mengembalikan sejumlah pinjaman yang diberikan oleh bank syariah beserta imbalannya sesuai dengan jangka waktu yang telah ditentukan sebelumnya. Variabel resiko pembiayaan diukur dengan rasio Non Performing Financing (NPF). 
Oleh karena dalam penelitian ini menunjukkan bahwa variabel pembiayaan bermasalah tidak berpengaruh terhadap variabel laba, ada faktor lain yang dapat mempengaruhi terhadap perkembangan laba. Seperti yang dijelaskan oleh Pramuka (2010) bahwa laba bersih suatu bank dipengaruhi oleh dua faktor, yakni volume pembiayaan dan resiko pembiayaan. Dikarenakan resiko pembiayaan tidak berpengaruh terhadap laba, maka masih ada variabel volume pembiayaan yang dapat mempengaruhi laba.

Dalam bisnis perbankan struktur kevangan berpengaruh positif terhadap profitabilitas. Artinya bila debt to equity meningkat maka menunjukkan semakin tinggi dana yang tersedia dan memberikan kesempatan pihak bank untuk mengelolanya berupa peningkatan kredit atau pembiayaan kepada masyarakat yang berarti memberikan peluang untuk peningkatan profitabilitas. (Pramuka, 2010)

Meskipun tidak sesuai hipotesis, hasil penelitian ini membuktikan bahwa meskipun adanya pembiayaan bermasalah yang dari waktu ke waktu semakin tinggi, laba yang didapatkan oleh bank umum syariah jumlahnya tetap naik. Hal ini menunjukkan bahwa kinerja bank umum syariah di Indonesia semakin baik.

Berkaitan dengan resiko pembiayaan yang ada, Islam telah menjelaskan bahwa dari manajemen resiko Islam yang menganjurkan untuk melakukan perencanaan agar lebih baik di masa yang akan datang (Rohman, 2012). Hal ini sesuai dengan firman Allah SWT dalam Q.S Al Hasyr ayat 18:

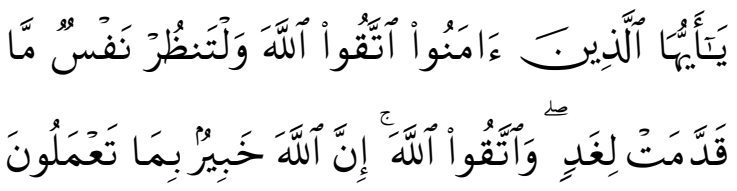
yā ayyuhā al-lażīna āmanū at-taqū 'I-Lāha waltanz̧ur nafsun 'm-ma qaddamat ligadin wa 't-Taqu 'I-Lāha inna 'I-Lāha khabīrun 'm-bimā ta'malūn.

"Hai orang-orang yang beriman, bertakwalah kepada Allah dan hendaklah Setiap diri memperhatikan apa yang telah diperbuatnya untuk hari esok (akhirat); dan bertakwalah kepada Allah, Sesungguhnya Allah Maha mengetahui apa yang kamu kerjakan."

Hal ini berarti setiap manusia harus memperhatikan yang telah diperbuat dengan melakukan pengawasan untuk hari esok. Kegiatan ini mencakup perencanaan, pengorganisasian, mengarahkan, dan melaksanakan (Rohman, 2012).

\section{Pengaruh Pembiayaan Murabahah terhadap Laba}

Berdasarkan hasil penelitian, variabel pembiayaan murabahah berpengaruh positif terhadap terhadap laba dengan probabilitas 0,001 dan tingkat pengaruh langsung sebesar 0,793. Hal ini berarti setiap kenaikan pembiayaan murabahah sebesar satu 
satuan maka akan meningkatkan laba sebesar 0,793. Dengan demikian, hasil analisis kuantitatif dalam penelitian ini sesuai dengan hipotesis sebelumnya, yaitu pembiayaan murabahah berpengaruh positif terhadap laba.

Pengaruh pembiayaan murabahah terhadap laba ini dapat dianalisis melalui dua jalur, yakni pengaruh lansung dan pengaruh tidak langsung. Sehingga hubungan (pengaruh) positif antara dua variabel tersebut dapat dijelaskan melalui dua alasan. Pada pengaruh langsung maupun tidak langsung membuktikan ada hubungan positif antara dua variabel, tingkat pengaruhnya adalah sebesar 0,793 untuk pengaruh langsung dan sebesar 0,053 untuk pengaruh tidak langsung.

Pembiayaan murabahah memiliki pengaruh langsung lebih tinggi daripada pengaruh tidak langsung terhadap laba. Hal ini dikarenakan pembiayaan murabahah merupakan salah satu komponen penyusun aset terbesar pada perbankan syariah. Pengelolaan pembiayaan murabahah akan menghasilkan pendapatan berupa margin/mark up. Dengan diperolehnya pendapatan mark up tersebut, maka akan mempengaruhi besarnya laba yang diperoleh bank syariah. Jika penyaluran pembiayaan tersebut dalam pengembaliannya berjalan dengan lancar, dimana semakin besar pendapatan maka semakin besar pula tingkat profitabilitas yang didapatkan oleh bank syariah (Oktriani,2011).
Hasil penelitian ini sesuai dengan penelitian yang dilakukan Rahman (2011) yang menunjukkan bahwa semakin tinggi pembiayaan murabahah yang merupakan salah satu jenis pembiayaan jual beli, maka semakin tinggi profitabilitas bank umum syariah yang diproksikan dengan Return On Asset. Penelitian ini juga sesuai dengan pendapat Muhammad (2008:96) bahwa pembiayaan murabahah yang diberikan oleh pihak bank akan menghasilkan margin/keuntungan bagi pihak bank. Kemudian keuntungan yang diperoleh pihak bank tersebut akan dihimpun beserta keuntungan pembiayaanpembiayaan yang lainnya dalam pool dana pendapatan yang kemudian akan disalurkan menjadi aset perusahaan, investasi dan modal. Dari ilustrasi di atas, dapat diketahui bahwa pengelolaan pembiayaan murabahah yang efektif akan dapat meningkatkan aset perusahaan.

\section{SIMPULAN}

Berdasarkan hasil analisis dan pembahasan pada bab sebelumnya, maka dapat disimpulkan, sebagai berikut: 1.Pembiayaan murabahah berpengaruh positif terhadap pembiayaan bermasalah bank umum syariah selama periode 2009-2013 dengan koefisien jalur 0,874 . Hal itu menunjukkan setiap terjadi kenaikan jumlah sebesar satu satuan pada jumlah pembiayaan murabahah maka akan meningkatkan jumlah 
pembiayaan bermasalah sebesar 0,874 satuan.

2.Pembiayaan bermasalah tidak berpengaruh terhadap laba bank umum syariah selama periode 20092013. Dengan demikian, setiap kenaikan jumlah pembiayaan bermasalah sebesar satu satuan maka tidak akan meningkatkan atau menurunkan nilai laba.

3.Pembiayaan murabahah berpengaruh positif terhadap laba bank umum syariah selama periode 2009-2013 dengan koefisien jalur 0,793. Hal itu menunjukkan setiap terjadi kenaikan sebesar satu satuan pada jumlah pembiayaan murabahah maka akan meningkatkan jumlah laba sebesar 0,793 satuan.

\section{DAFTAR PUSTAKA}

Antonio, Muhammad Syafi'i. 2001. Bank Syariah: Dari Teori Ke Praktik. Jakarta: Gema Insani Press

Arifin, Zainul. 2005. Dasar-Dasar Manajemen Bank Syariah. Jakarta: Alvabet

Ascarya. 2007. Akad \& Produk Bank Syariah. Jakarta: RajaGrafindo Persada

Bungin, Burhan. 2005. Metode Penelitian Kuantitatif: Komunikasi, Ekonomi, dan Kebijakan Publik Serta IlmuIlmu Sosial Lainnya. Jakarta: Kencana Prenada Media Grup

Djamil, Fathurrahman. 2012. Penyelesaian Pembiayaan Bermasalah di Bank Syariah. Jakarta: Sinar Grafika
4.Dari hasil analisis jalur ini terdapat pengaruh tidak langsung antara pembiayaan murabahah terhadap laba melalui variabel endogen intervening yaitu pembiayaan bermasalah. Hasil analisis jalur untuk pengaruh tidak langsungnya sebesar 0,053 . Hal tersebut menunjukkan bahwa pengaruh tidak langsungnya lebih kecil dibandingkan dengan pengaruh langsungnya yakni 0,793 karena dari hasil penelitian ini adalah bahwa pembiayaan bermasalah tidak berpengaruh terhadap laba. Oleh karena itu, analisis variabel pembiayaan murabahah terhadap laba hanya bisa dianalisis melalui pengaruh langsung.

Fauzan, Fachrul. 2012. Pengaruh Tingkat Risiko Pembiayaan Musyarakah dan Pembiayaan Murabahah Terhadap Tingkat Profitabilitas Bank Syariah (Studi Pada Bank Aceh Syariah Cabang Banda Aceh),

(Online), (www.academia.edu, diakses 5 Agustus 2014)

Ferdinand, Augusty. 2006. Metode Penelitian Manajemen. Semarang: Badan Penerbit Universitas Diponegoro

Hapsari, Nadhifa Alim. 2013. Pengaruh Tingkat Imbalan Sertifikat Bank Indonesia Syariah (SBIS) terhadap Tingkat Pembiayaan dan Profitabilitas Bank Umum Syariah di 
Indonesia. Skripsi tidak diterbitkan. Surabaya FEB Universitas Airlangga Kuncoro, Mudrajad. 2002. Manajemen Perbankan: Teori dan Aplikasi. Yogyakarta: BPFE

Mankiw, N. Gregory. 2000. Teori Makro Ekonomi. Jakarta: Erlangga

Muhammad. 2004. Manajemen Dana Bank Syariah. Yogyakarta: Ekonisia

Ekonomi Islam. Jakarta: Gema Insani Press

2011. Manajemen Bank Syariah. Yogyakarta: UPP Sekolah Tinggi Manajemen YKPN

Nurkhosidah, Siti. 2009. Analisis Pengaruh Variabel Non Performing Financing, Penyisihan Penghapusan Aktiva Produktif, Financing to Deposit Ratio, Biaya Operasional Per Pendapatan Operasional Terhadap Profitabilitas Pada Bank Syariah Mandiri. Skripsi tidak diterbitkan. Yogyakarta Fakultas Syariah Universitas Islam Negeri Sunan Kalijaga

Oktriani, Yesi. 2011 . Pengaruh Pembiayaan Musyarakah, Mudharabah dan Murabahah terhadap Profitabilitas (Studi Kasus Pada PT. Bank Muamalat Indonesia, Tbk.), (Online), (journal.unsil.ac.id diakses 19 September 2013)

Pramuka, Bambang Agus. 2010. FaktorFaktor yang Berpengaruh Terhadap Tingkat Profitabilitas Bank Umum Syariah, (Online), (www.academia.edu diakses 9 Maret 2014)

Riduwan, dan Kuncoro. 2008. Cara Menggunakan dan Memakai Analisis Jalur (Path Analysis). Bandung: Alfabeta

Rohman, Moh Thoifur. 2012. Aplikasi Manajemen Risiko Dalam Pengelolaan Dana Takaful Pendidikan (Studi Pada PT. Asuransi Takaful Keluarga Cabang Semarang). Skripsi tidak diterbitkan. Semarang Fakultas Syariah Institut Agama Islam Negeri Walisongo

Rubby, Muhammad. 2013. Analisis FaktorFaktor yang Mempengaruhi Profitabilitas (ROA) Bank Umum Syariah yang Terdaftar di Bursa Efek Indonesia Periode 2008-2011. Skripsi tidak diterbitkan. Medan FE Universitas Sumatera Utara

Santoso, Singgih. 2007. Panduan Lengkap Menguasai SPSS 16. Jakarta: Elex Media Komputindo

Siamat, Dahlan. 2004. Manajemen Lembaga Kevangan. Jakarta: Lembaga Penerbit Fakultas Ekonomi Universitas Indonesia

Sugiyono. 2010. Metode Penelitian Kuantitatif Kualitatif dan R\&D. Bandung: Alfabeta 